\title{
Empirical Research in Vocational Education and Training Preface Volume 1 Issue 1 March 2009
}

One of the aims of Switzerland's vocational and professional education and training (VPET) policy is to implement evidence-based development. In order for that to be possible, its political actors are dependent on outstanding research findings from a broad range of disciplines relating to VPET. I am therefore particularly glad that with the publication of this journal we are able to contribute to the international discourse on VPET research, and thus to the durable development of one of the most important areas of the education and employment system.

In Switzerland, two-thirds of young people complete an apprenticeship to enter the labour market. The availability of further formal qualifications at professional level means that a large proportion of the working population obtains professional qualifications in the tertiary non-university sector. Every year the number of people obtaining such qualifications is slightly higher than those obtaining qualifications from universities, which goes some way to explaining the relatively low university graduation rate in international comparison. For decades this human capital has formed the backbone of the Swiss economy and probably contributes to its strong capacity for innovation. Due to the high degree of permeability in the education and employment system as a whole, it is possible over the course of a person's working life, to pass from the vocational or professional to the academic education path and vice versa, which consequently increases the appeal of vocational and professional education and training. Switzerland is unique in that respect, which is why there is a particular need for more knowledge and research.

In view of the ever more rapidly changing conditions on the labour market, but also due to the increasing internationalisation of companies and their value-added chains, it is vital to obtain significant academic findings on these mechanisms and anticipate future developments. This should help to maintain positive effects such as low youth unemployment, high labour productivity, the integration of young people with a migration background and high labour market mobility. It should also enable us to continuously adapt the vocational and professional education and training system to new challenges.

Until the beginning of the $21^{\text {st }}$ century, Switzerland was unable to base developments in its VPET system on significant academic findings. Too few university faculties were involved in empirical and systematic studies in the field of vocational and professional education and training. This became apparent during the drafting of the fourth Vocational and Professional Education and Training Act, which is why legislators granted the federal government the necessary mandate to act. Due to the fact that the bottomup approach resulted in few promising results, the Federal Office for Professional Education and Technology (OPET) decided to ensure that appropriate capacity was put in place at Switzerland's universities to conduct targeted research in specific VPET areas and play a part in encouraging the next generation of researchers. Since 2003, six 'Leading Houses' have been created. Professors with expertise in a relevant research field were able to apply to chair a Leading House. They presented a research plan, set out how they intended to encourage young researchers and how they planned to expand the research community, both nationally and internationally, and disseminate the findings in publications. A steering committee consisting of national and international figures from the worlds of science, VPET and labour market policy assesses the submissions and advises the OPET on the allocation of Leading House status. An internationally composed scientific advisory board is responsible for assuring the quality of the research conducted by each Leading House. It assesses the quality of research on behalf of the Federal Office and submits recommendations for further development.

A whole of host of books, articles, papers and dissertations have since been produced by the six Leading House research networks. Numerous young researchers have also presented and discussed their findings at conferences. The Federal Institute for Vocational Education and Training, which in addition to monitoring the development of professions is responsible for training teaching staff and in-company training staff, ensures that the research findings are recognised by practitioners, put directly into practice or prompt pilot schemes. 
In addition to these activities, our aim in publishing this journal is to encourage debate on the results of VPET research, as well as critical reflection on published findings, and to learn from other countries. In order for policymakers and legislators to be able to make well-informed decisions and bring about the desired effects, we need to have greater knowledge on a wide range of issues. For example, are tax breaks an effective way of increasing the willingness of host companies to offer training or of increasing the take-up of further training? How does the internationalisation of a company affect occupations and the necessary qualification profile? What lasting qualifications do young people need in order to be prepared for lifelong learning? What do we mean by 'employability' in the globalised economy of the future? How can qualifications be compared and assessed when VPET systems are so different? Is the VPET system efficient and effective in view of structural changes in the economy? Are equal opportunities to enter the labour market available to all young people? These and other questions are of interest to VPET workers on the ground, as well as to political actors. This journal will present the findings of such research and seek to raise new questions.

We would like to thank all researchers who are contributing to improving the knowledge of aspects of and issues relating to VPET systems around the world and its dissemination. Your contributions are valuable building blocks on the path to a more effective steering of the vocational and professional education and training careers of the majority of a country's population. Particular thanks go to the editorial board which ensures that this journal is at the cutting edge of research and able to have a worldwide impact in the academic community.

We are glad to receive all contributions and look forward to any submissions resulting from research or responses to published articles. The debate surrounding such research should be insightful and beneficial to all future generations.

\section{Dr. Ursula Renold}

Director, Federal Office for Professional Education and Technology 